\title{
Remote sensing applications for the assessment of the geomorphic response of fluvial systems to the Holocene Climate Changes
}

\author{
Giulia Iacobucci (1)
}

\author{
(1) Earth Sciences Department, Sapienza University of Rome, Roma, Italy. \\ Corresponding author e-mail: giulia.iacobucci@uniroma1.it \\ Document type: Article. \\ Manuscript received 31 March 2021; accepted 04 October 2021; editorial responsibility and handling by M. Pipan.
}

\section{ABSTRACT}

During the Holocene, the Tigris-Euphrates river system (Lower Mesopotamian Plain) was characterized by a complex morphodynamic due to climatic fluctuations, shoreline shifting, and human activities. Within a wide and barren floodplain with low elevation ranges, a remote sensing multi-sensor approach is suitable to identify the main geomorphological features and associated geomorphic processes. Optical and multispectral imagery (TerraColor and Landsat 8) are adopted for the preliminary visual inspection and the computation of multispectral indices (NDVI and Clay Ratio), as well as for the supervised classification. The topographic analysis of the microrelief is integrated reclassifying two DEMs (AW30D30 and GDEM2) to highlight the peculiar configuration of the drainage system, which channels are several meters above the surrounding floodplain. This approach allows the investigation of the study area through large and medium scale, identifying active and abandoned channels discerning between active and abandoned avulsion processes and distinguishing crevasse channels, levees, and deposits. In like manner, human features are recognized, allowing the evaluation of humanenvironmental interactions.

KEY WORDS: Remote sensing, multispectral analysis, supervised classification, topographic analysis, Lower Mesopotamian Plain, avulsion processes, crevasse splays.

\section{INTRODUCTION}

The intervals of time with low climate variability must be considered as exceptions than the normality (Bertlein, 2006), since several internal and external forcing influence the climate system. The last $12 \mathrm{ka}$ are characterized by high-frequency low-amplitude climate oscillations, well preserved by Holocene stratigraphic records. Sea-level changes, variation of geomorphological and hydrological processes, vegetation development, and faunal migration are common evidence of the Holocene Climate Changes (HCC), which highly impacted early human societies, adding further proof of climate fluctuations through archaeological records (Bertlein, 2006; Walker et al., 2012; Kaniewsky et al., 2013; Walker et al., 2018).

At the beginning of the 2000s, Bond et al. (2001) recognized nine shifts in ocean surface hydrography during the last 12 ka years: multi-century scale changes between cold and warm (or dry and wet) with the cyclical occurrence of about 2000-2800 and 1200-1500 years (i.e., Bond Events). Anyway, only on $14^{\text {th }}$ June 2018 , the International Union of
Geological Sciences officially ratified the subdivision of the Holocene into three stages (i.e., Greenlandian, Northgrippian and Meghalayan) on the basis of the world's Bond Events at 8.2 and $4.2 \mathrm{ka}$ (Walker et al., 2018).

The identification of the HCC through the landscape changes is a challengeable opportunity for understanding how such climate oscillations modified boundary conditions, influencing erosional and depositional processes of a sensitive geomorphological system like rivers. Since the fluvial systems have a worldwide distribution, they respond differently to the HCC from region to region, and each fluvial landform and process is influenced not only by climate but also by eustatism, tectonics and human activities. Fluvial systems respond to these allogenic factors i) changing the discharge regime, ii) changing the fluvial pattern, and iii) changing longitudinal profiles through aggradation or incision. The modification of discharge regime and fluvial pattern are the most direct responses to a rapid climate change, despite the fluvial response is frequently spatially non-uniform, complicating the recognition and interpretation (Blum \& Törnqvisit, 2000, Macklin \& Lewin, 2015).

The Holocene fluvial environments also record the intensifying role of the early human societies during the Bronze Age, especially where they firstly settled for satisfying water needs. Due to the rather dry environments where these ideal habitats occurred, the Early river Civilization dealt with common adverse conditions, like changes in magnitude and frequency of floods, droughts, and drastic river channels modifications (Macklin \& Lewin, 2015). Between 4.2 and $3.9 \mathrm{ka}$, different societies based on cereal-agriculture and with developed politicalsocietal organizations synchronously collapsed in the Mediterranean, the Levant, Egypt, Turkey and Mesopotamia, where the changes in the hydromorphic regime frequently caused a disturbance on natural inundation or managed irrigation (Macklin and Lewin, 2015; Weiss, 2016; Benjamin et al., 2017).

The Lower Mesopotamian Plain is an ideal study area where the Holocene morphodynamics of the TigrisEuphrates fluvial system has been insignificantly influenced by tectonics (Abdulnaby et al., 2020), but where the irrigation agriculture and the organised society occurred as early as the Lower Holocene and completely altered the 
surrounding environment digging canals, breaking levees, and avoiding channel siltation (Roberts, 2014). Moreover, the maximum marine ingression of the Persian Gulf at 6000 yr BP deeply influenced the delta progradation and the following shoreline south-eastward migration (Kennet \& Kennet, 2006; Bogemans et al., 2017).

Remote sensing technology allows collecting numerous kinds of information over wide areas, through multitemporal acquisitions which are fundamental in dynamic environments like rivers, deltas and coasts. The variety of scales and resolutions allows the analysis of the images through several methods: the topographic analysis of DEMs lets map the floodplain landforms and architectural characteristics while the analysis of multispectral imagery is suitable for collecting measurements of the flood events, sediment transport and recognizing pattern changes (Syvitski et al., 2012).

In order to define the geomorphological response of fluvial systems to the HCC, I discuss the following topics in the Lower Mesopotamia area: i) How did the fluvial morphodynamics adjust to the HCC in the study area? ii) Can we recognize the state of activity of the avulsion processes through a complete remote sensing approach over a wide study area?

\section{STUDY AREA}

The Mesopotamian Plain (hereafter MP) is a wide lowland of about 116,000 square $\mathrm{km}$, completely included in the Tigris-Euphrates watershed that guarantees its fertility, rising out in the Turkish Mountains and reaching about 2800 and $1850 \mathrm{~km}$ of length, respectively. Both rivers have a strongly seasonal discharge due to the Mediterranean climate of their mountainous headwaters, in addition to the southward decrease of the mean annual precipitation, reaching the arid-semiarid climate (Garzanti et al., 2016; Jotheri et al.; 2018).

The MP can be subdivided into five distinct physiographic regions: i) the northern and the northeastern mountainous region (High Folded and Imbricate Zones), ii) the foothills (Low Folded Zone), iii) the western desert (Inner Platform), iv) the central Jazira region (the Upper Mesopotamian Plain or UMP) and v) the southern lowlands (the Lower Mesopotamian Plain or LMP). Both the UMP and LMP belong to the Mesopotamian Foredeep, generated by the subduction of the Arabian Plate under the Eurasian (Iranian) Plate, in addition to the northernmost area of Jazira Plain and the Persian Gulf (Fig. 1A) (Sissakian, 2013).

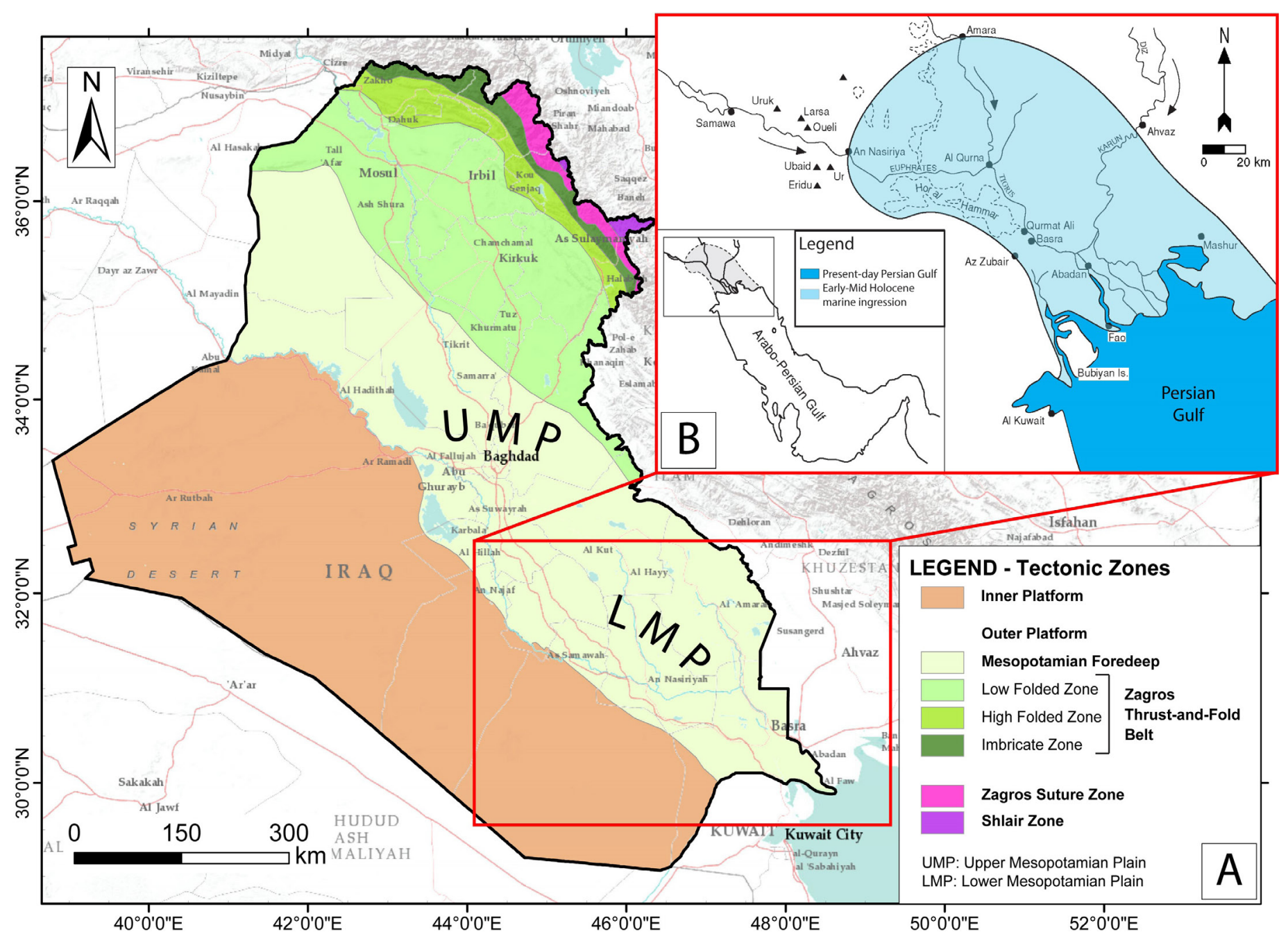

Fig. 1 - The Iraqi territory subdivided into its main tectonic zones, modified from Sissakian 2013 (A), and the maximum marine ingression of the Persian Gulf at 6000 yr, modified from Kennet \& Kennet 2006 (B). 
The LMP is characterized by different sub-environments such as freshwater lakes, brackish water lakes, saline lakes and their surrounding marshes (locally called Ahwar), anastomosing and meandering rivers, distributary channels, irrigation canals, levees above the surrounding floodplain up to 3-4 meters and crevasse splays, shaping the landscape so much that is better defined as waterscape (Jotheri et al., 2018).

The area is filled by a thick alluvial sequence, deposited mainly during the Quaternary with a maximum thickness of about $180 \mathrm{~m}$ near Basrah. The facies distribution is mostly controlled by climate, sea-level changes, and sedimentation rate: the Pleistocene-Holocene stratigraphic sequence belongs to fluvial, deltaic, and lacustrine deposits, mainly of the Tigris and Euphrates rivers, in addition to the estuarine, marine and aeolian sediments deposited during the Holocene, showing a wide range of environments that are prevalently made up of sand, silt, loam and clay (Milli \& Forte, 2019). During the Holocene, the LMP has been strongly influenced by sea-level oscillations, which played a key role in shaping the environment: the earlymid Holocene sea-level rise produced general inland, northward migration of the Persian Gulf shoreline to which followed, during the late Holocene, continuous seaward migration of the shoreline due to the Tigris and Euphrates delta progradation, in addition to a slight sea-level fall of about 2-3 m (Fig. 1B) (Lambeck, 1996; Kennett \& Kennett, 2006). Specifically, about 15.000 yr BP, the global sea level was lower than the present one of about $100 \mathrm{~m}$ and the Persian Gulf was a subaerial basin where the TigrisEuphrates-Karun river system flowed up to the Strait of Hormuz as the Ur-Shatt River. Following $15.000 \mathrm{yr}$ BP, the marine transgression formed the Persian Gulf: during the early Holocene, the Persian Gulf registered one of the highest sea level rises of about $1 \mathrm{~cm} / \mathrm{yr}$ (Siddal et al., 2003). Between 10.000 and $6000 \mathrm{yr} \mathrm{BP}$, the increasing rainfalls across the Arabia Peninsula and LMP allow inundating the entire Persian Gulf, shifting the shoreline northward. The sea level reached its maximum elevation of about 2-3 m above the modern level during the moistest period about 6000 yr BP (Lambeck, 1996), and several boreholes in the LMP confirm the marine-brackish conditions between the modern cities of Nasiriyah and Al-Amara, demonstrating the prevail of estuarine conditions about 6000 yr BP (Aqrawi, 2001; Kennet \& Kennet, 2006; Milli and Forte, 2019). During the Middle Holocene, the deceleration of sea-level rise and the aridification of climate conditions favoured sediment infilling of the estuary and the fluvial processes of the Tigris and Euphrates rivers prevailed, developing a river-dominated delta (Kennet \& Kennet, 2006). The delta progradation shifted southward the Persian Gulf shoreline up to the present position, with a maximum rate between 6000 and 4000 yr BP during the wettest conditions, whereas it slowed significantly during the driest period of the Late Holocene (Aqrawi, 2001; Kennet \& Kennet, 2006; Milli and Forte, 2019). Nowadays, the mid-Holocene riverdominated delta has been completely replaced by a tidedominated delta, where the fluvial processes are strongly reduced by the Persian Gulf tides which vary between 1-3 m (Yacoub, 2011).

Therefore, the LMP can be considered as a wide aggradational geomorphological unit, where the Tigris and the Euphrates favoured channel processes, forming levees above the floodplain, meanders, scrollbars, oxbow lakes, crevasse splays, distributary channels and marshes. Both the main rivers and the numerous distributaries are subjected to changes in their morphodynamic and pattern due to channel gradient and confinement, grain size and sediment supply, riverside vegetation and human impacts (Yacoub, 2011; Jotheri et al., 2018). Fluvial avulsions are one of the most frequent processes in the study area; they occur because of an abrupt shift of the whole channel belt from one location to another, favouring the formation of a new watercourse. This process mainly occurs during flood events and requires the bed of the new course to be topographically lower than the old channel belt. As the inception of the avulsion process requires an energetic water flow, it is quite logical to consider this process connected with the widening of a channel on a crevasse splay, becoming the key geomorphological feature to understand the fluvial morphodynamic in lowland areas (Bridge \& Demicco, 2008). A crevasse splay typically shows a lobate sediment accumulation area, fan-shaped in plan with an upward convexity and contain a system of a distributive multi-channel system (Goudie, 2004; Aslan, 2006). Crevasses are particularly important landforms both for the recognition of the anastomosed fluvial environment and the archaeological surveys in order to identify the earliest human settlements that exploited the crevasse channels as irrigation canals (Roberts, 2014).

\section{MATERIALS AND METHODS}

The detailed description and validation of the methodological approach adopted for a remote study of the wide LMP have been discussed in Iacobucci et al., 2020.

The LMP has been investigated through Landsat 8 optical and multispectral data, while the Digital Elevation Models (DEMs) have been obtained by two optical derived and freely available datasets with a ground resolution of 1 arcsec (ca. $30 \mathrm{~m} \mathrm{cell}^{-1}$ ). Each dataset guarantees the investigation of a wide area, favouring a multi-temporal analysis and a different scale of investigation.

The ESRI ${ }^{\circledR}$ TerraColor dataset, included in the ESRI® ArcGIS 10.6 software package, has been adopted during the preliminary visual inspection for recognizing active meandering and anastomosing channels, the visual traces of abandoned channelized flows, and the superimposed modern canals network through some useful features like tone, pattern, shape and association-situation (Fig. 2B). In true-color images, the tone of the abandoned channels is mainly brownish-greyish, while their levees are vegetated and present a green tone only when a proximal man-made canal occurs; indeed, it is not rare that the modern canals follow the same direction of the abandoned channels, making difficult their distinction. The abandoned channel pattern is frequently sinuous and meandering, but in the areas where the human impact on the landscape is null, the anastomosing pattern is still preserved. Finally, the specific association-situation takes into account the occurrence of other fluvial features like scroll bars or crevasse splays.

Alluvial deposits of different ages can be distinguished using multispectral imagery, where different reflectance properties due to changes in chemistry, mineralogical composition and micro-relief are highlighted. Therefore, multispectral images can be adopted for getting information about the types of sedimentary deposits and 
so for discerning landforms (D'Arcy et al., 2018; Iacobucci et al., 2020).

Landsat 8 carries the Operational Land Imager (OLI) and the Thermal Infrared Sensor (TIRS). OLI works on nine spectral bands, including a panchromatic one, while TIRS works on the last two bands (Sekandari et al., 2020). Besides its brief time life (i.e. since 2013), Landsat 8 is one of the best multispectral satellites thanks to the eleven bands with several spatial resolutions (i.e., the panchromatic band with $15 \mathrm{~m}$, eight bands with $30 \mathrm{~m}$ and the TIRS bands with $100 \mathrm{~m}$ ), suitable for computing spectral indices like NDVI (Normalized Difference Vegetation Index) and CR (Clay Ratio) and for carrying on supervised classification through four main classifiers available in ENVI 5.3 (Mahalanobis, Maximum Likelihood, Minimum Difference, Spectral Angle Mapper or SAM).

Both NDVI and CR allow assessing the seasonal vegetation variability, the lateral shifting degree of the channels, identifying the areas where human activities have a lesser impact, and recognizing the activity of the distributaries and crevasse channels. Moreover, the supervised classification lets to cluster each pixel into a specific class defined by the Regions of Interest (ROIs). The target feature of a crevasse splay has been distinguished into three main sub-features (i.e., ROIs), where the spectral signature has been extracted: (i) active and abandoned channel; (ii) active levee; (iii) active and abandoned deposit.

Considering the climatic regime of the LMP, two periods characterized by opposite moisture conditions have been selected including the wettest season (October-December) and the driest one (July-August) of 2017. Consequently, the selected Landsat 8 images present different conditions of reflectance because of variation in soil moisture, vegetation cover and percentage of suspended materials along watercourses, allowing to properly interpret Earth surface landforms and processes.

The topographic data of the entire LMP has been furnished by two freely available 1 arcsec DEMs, in order to enhance the reliability of the topographic elaborations through the comparison and mutual confirmation of different sources (Iacobucci et al., 2020). The Advanced Land Observing Satellite (ALOS) realised in 2016 the first version of AW3D30, while the second adopted dataset is the GDEM2 realised in 2011 by the Advanced Spaceborne Thermal Emission and Reflection Radiometer (ASTER).

The analysis and interpretation of the micro-relief have been favoured by the generation of colour-coded DEMs with a 1-5 $\mathrm{m}$ re-classification scheme starting from the sea level up to the maximum elevation of the study area (with a major interval frequency for the first $30 \mathrm{~m}$ a.s.l.). This re-classification is helpful for the visual inspection of the floodplain features characterized by low or very low topographic relief such as canals and channels' levees, archaeological mounds and crevasse splays. Indeed, the LMP drainage system can be defined as a "suspended divergent drainage system", where the watercourses are topographically above the surrounding floodplain. As regards the crevasse splays, their distinction between active and abandoned has been evaluated through the drawing of four elevation profiles: the first profile is along the dip direction, proximal to the adjacent floodplain, to evaluate the limit of distal crevasse deposits, while further profiles are along the cross direction in the proximal, middle, and distal sectors of the crevasse (Iacobucci et al., 2020).

\section{RESULTS}

The small-scale investigation of the LMP through a multi-sensor remote sensing approach returned the mapping of the multi-channel fluvial system and the reconstruction of the maximum marine ingression of about $6000 \mathrm{yr}$ BP. Indeed, the mapping of the abandoned multi-channel system of the LMP is the first essential step from which the following ones started (i.e., the mediumscale investigation of the avulsion processes).

As concerning the reconstruction of the maximum marine ingression and its shoreline at $6000 \mathrm{yr} \mathrm{BP}$, it was obtained through the raster reclassification of the AW3D30 elevation data, using the Reclassify tool available in ArcGIS 10.6. Selecting two reclassifying classes (i.e., values below $5 \mathrm{~m}$ and values above $5 \mathrm{~m}$ ), a plausible reconstruction of the shoreline morphology during the maximum marine ingression is feasible, considering the geological and sedimentological evidence which prove the Persian Gulf reached the modern cities of Nasiriyah and Al-Amara (Fig. 2A). Despite Lambeck (1996) proposed a sea-level higher than the modern one of about $2-3 \mathrm{~m}$ in the area of Al-Faw, the adopted sea-level value of $+5 \mathrm{~m}$ is exclusively nominal, considering the influence of "surface artefacts" that typically characterized Digital Surface Model like AW3D30.

The reconstruction of the abandoned multi-channel system and the shoreline morphology focus attention on the occurrence of a river-dominated delta during the midHolocene, where the anastomosed pattern and related avulsion processes prevailed.

In order to identify active and abandoned avulsion processes, the following medium-scale investigation leads to comparing the spectral and morphologic differences between the active and abandoned crevasse splays, previously recognized through the visual inspection. Among the identified 200 crevasse splays, four of them have been selected based on their size higher than $50 \mathrm{~km}^{2}$, where sub-features like channels, levees, and deposits are well developed and recognizable.

The topographic analysis of the crevasse sections allows to identify several differences both in the alongdip and cross-direction distribution of the deposits: active crevasse splays show an emphasized convex-up profile at the proximal sector, gradually flattening toward the floodplain; while the cross-sections show the notable differences mainly due to the different activity of the crevasse channels and the relative distribution of sediments. Instead, the abandoned crevasse splays present rather different geomorphological and geometric characteristics, mostly due to the re-working of their deposits. Generally, the proximal deposits show the lowest thickness, while the middle sector is the thickest, flattening toward the distal sector (Fig. 3).

The multispectral satellite imagery analysis improves the identification of crevasse sub-features and the discerning between active and abandoned crevasse splays (as reported in Iacobucci et al., 2020). The most evident difference in the NDVI computation is the occurrence of vegetation exclusively on active crevasses, with the highest values along the crevasse channels in the proximal and middle sectors; otherwise, the scarce occurrence of vegetation in the abandoned crevasses is chiefly due to surrounding crops and canals. The CR lets to identify the activity of crevasse channels, discerning between transportation and 


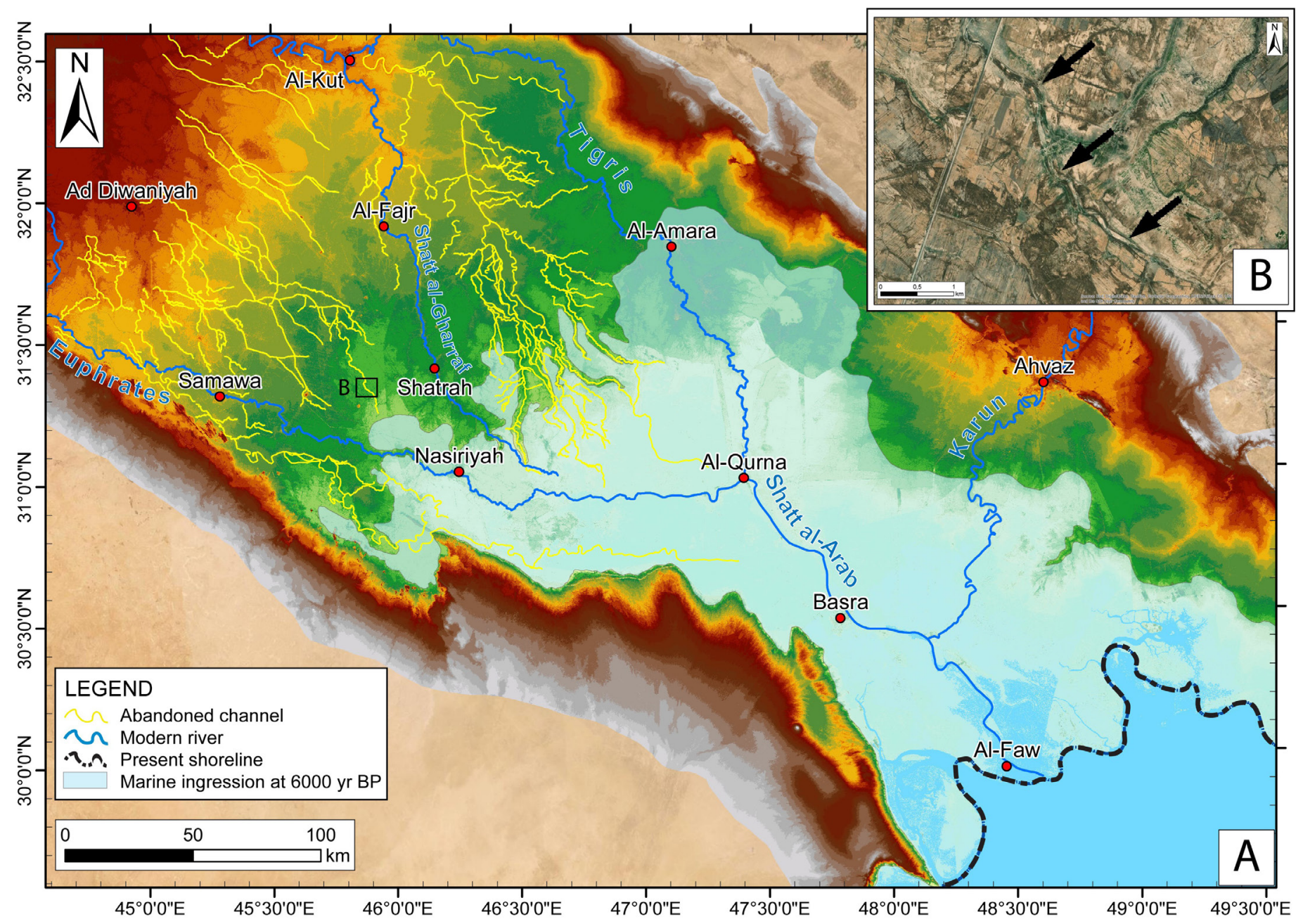

Fig. 2 - The reconstruction of the early Holocene waterscape of the LMP with the abandoned multi-channel fluvial system and the maximum marine ingression of the Persian Gulf (A). TerraColor example of an abandoned channel (B).

depositional sectors. The highest values of $\mathrm{CR}$ are along active crevasse channels, but also on their banks, leading to identify the levees; differently, the abandoned crevasses seem to be completely free of clayey deposits, except for some areas where human activity can be detected.

Different classification methods were adopted for the supervised classification and different iterations were carried on, selecting the most accurate results obtained after the computation of confusion matrices. The Mahalanobis and Maximum Likelihood are the suitable methods for discerning crevasse channels, levees and deposits of active landforms, and partially recognizing the abandoned crevasse channels and deposits. Moreover, especially for the active crevasses, both of these methods recognize several crevasse channels beyond the distal sector. The features of the abandoned crevasses are less recognizable, except for the abandoned channels in the proximal and middle sectors. Some spurious pixels without any typical shape are erroneously categorized as active channels, decreasing the accuracy of abandoned crevasse classification. As concerning the last two methods, Minimum Distance and SAM, their overall accuracy is lower, and their classification is poorly comparable with the ground-truth. The only active features recognized by
Minimum Distance and SAM are the main channels and the distal deposit, while the abandoned crevasses are scarcely or totally wrong classified.

\section{DISCUSSION AND CONCLUSIONS}

The methodological approach allowed to combine the data from digital elevation datasets to the outcomes of satellite multispectral imagery analysis, for detecting and mapping both fluvial landforms and anthropic activities in a wide and remote area like the LMP. Moreover, the low relief increased the difficulties in detecting fluvial avulsion processes, but it facilitates the recognition of fluvial landforms thanks to their above-floodplain configuration.

The combination of the topographic analysis of the micro-relief and the multispectral satellite imagery analysis successfully allowed recognizing crevasse splays, especially favouring the re-mapping of active landforms (Iacobucci et al., 2020). Indeed, the topographic analysis of the micro-relief lets to detect active crevasse splays through the "above-floodplain" configuration of their channels and levees; moreover, when the profile trace includes the surrounding floodplain, the detection of crevasse deposit 

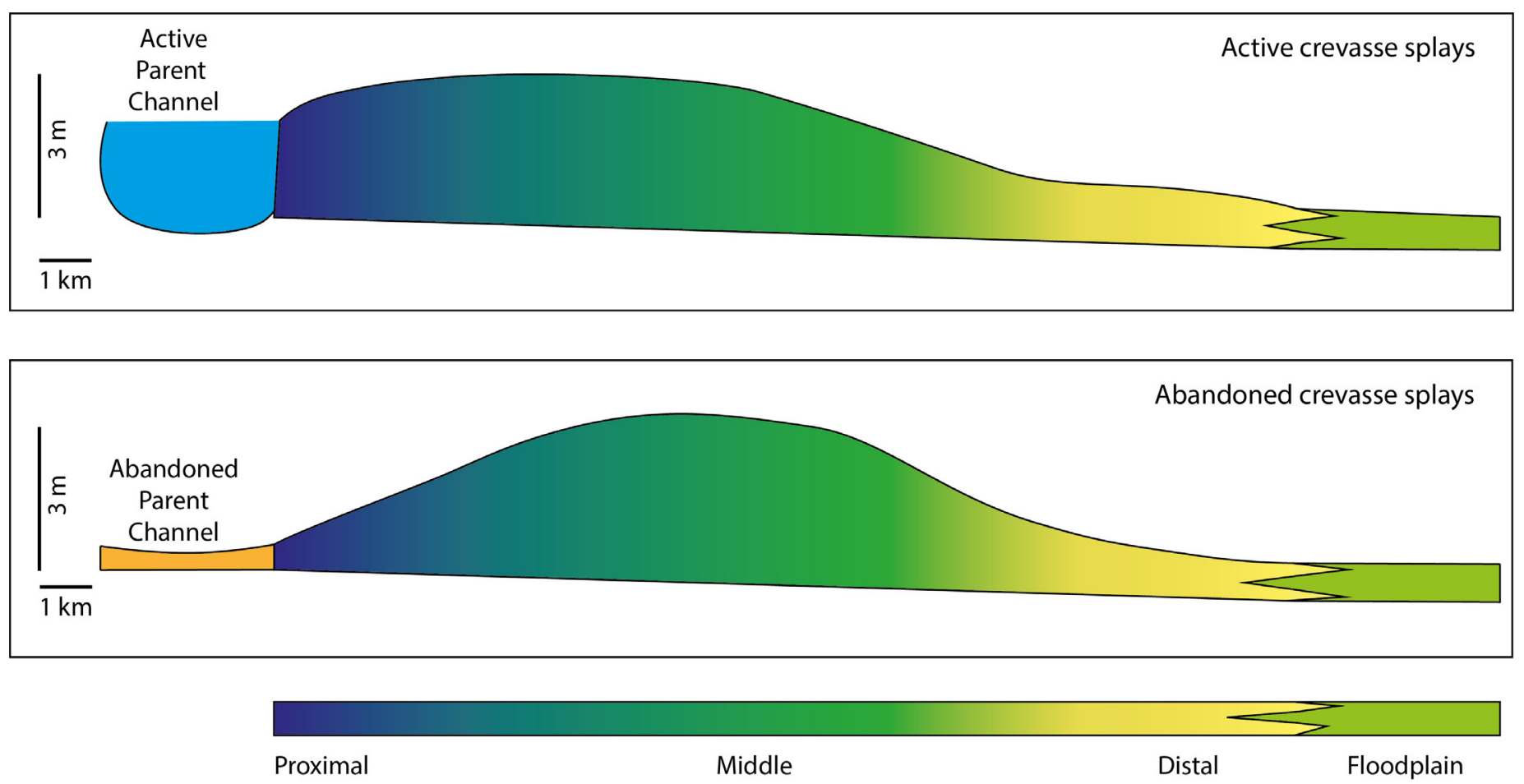

Fig. 3 - Along-dip conceptual altimetric profiles of typical active and abandoned crevasse splays (Iacobucci et al., 2020).

and its edge is easier. Despite the active crevasse channels and levees are frequently above the crevasse deposit, the height above the floodplain of the abandoned crevasse deposit is frequently the only characteristic for recognizing abandoned landforms.

The micro-relief analysis requires the multispectral analysis which can enhance the recognition of vegetation and clayey deposits. Indeed, the computation of NDVI and $\mathrm{CR}$ allows to assess the mobility of crevasse channels, the spatial distribution of the finest sediment and to compare the channelized/unchannelized flow. In particular, CR is useful to recognize the in-channel clay like the last deposits of a flood event when the floodwater goes back toward the parent channel due to the decrease of river discharge below the bankfull capacity. Anyway, the most undoubted interpretations derive from the supervised classification where the re-mapping and the differences in crevasse shape are emphasized. A wider proximal sector is due to the occurrence of different sub-splays and the coalescence among adjacent avulsion processes, which should lead to stretching of the crevasse channels, developing the crevasse splay mainly in the along-dip direction. The along-dip development is also due to the depth of crevasse channels: deepest crevasse channels are mainly in the proximal and middle sectors, preventing the overflow, while in the distal sector the crevasse channels are shallow, favouring the overflow. As already evidenced in Iacobucci et al., (2020), each crevasse splay is composed of various sub-fan-shaped deposits (i.e., single splays), each of which is due to the occurrence of a single flood event. The spatial distribution of the crevasse channels, levees, and deposits allows the recognition of these sub-splays, arranging the entire crevasse into a hierarchical framework (Fig. 4). The frequency and the intensity of the flood events decrease until the abandonment of the crevasse splays, leaving a relict landform, which deposit can be re-organized by aeolian processes. Especially, the integration of the topographic analysis micro-relief with the multispectral analysis leads to recognizing how the typical convex-up profile of the deposit is modified because of the spatial distribution of single splays, the depth of active crevasse channels, vegetation occurrence, the aeolian reworking of abandoned deposits, and human activities.

The potential onset of a new watercourse where crevasse splays occur, make these landforms a key feature for reconstructing the abandoned anastomosed distributary system of the LMP. Moreover, the avulsion processes favoured the irrigation of croplands and the development of the early settlements (Jotheri et al., 2019). Thus, the crevasse splays assume dual importance in the study area, both for the reconstruction of the Holocene multi-channel fluvial system and the geoarchaeological surveys of the numerous ancient settlements. Moreover, at present, a correct and accurate mapping of the active crevasse splays can contribute to better management of the water resource, supporting sustainable agriculture, avoiding water wastage, and limiting the hazard to people and infrastructure (Leenman \& Eaton, 2021).

The short note summarizes the state-of-the-art and the most relevant results obtained during my three-year $\mathrm{PhD}$ project on the identification of the geomorphological responses of the fluvial systems to the HCC, considering a wide, barren floodplain like the LMP. Here, natural and anthropic processes coexist, leading to evaluating the mutual interaction between the fluvial-deltaic processes and the water management. Moreover, the obtained results can contribute to the evaluation of the risk associated alongside lowland areas to the formation and development of crevasse splays. Indeed, the multi-sensor remote sensing approach is appropriate for investigating extended areas, 

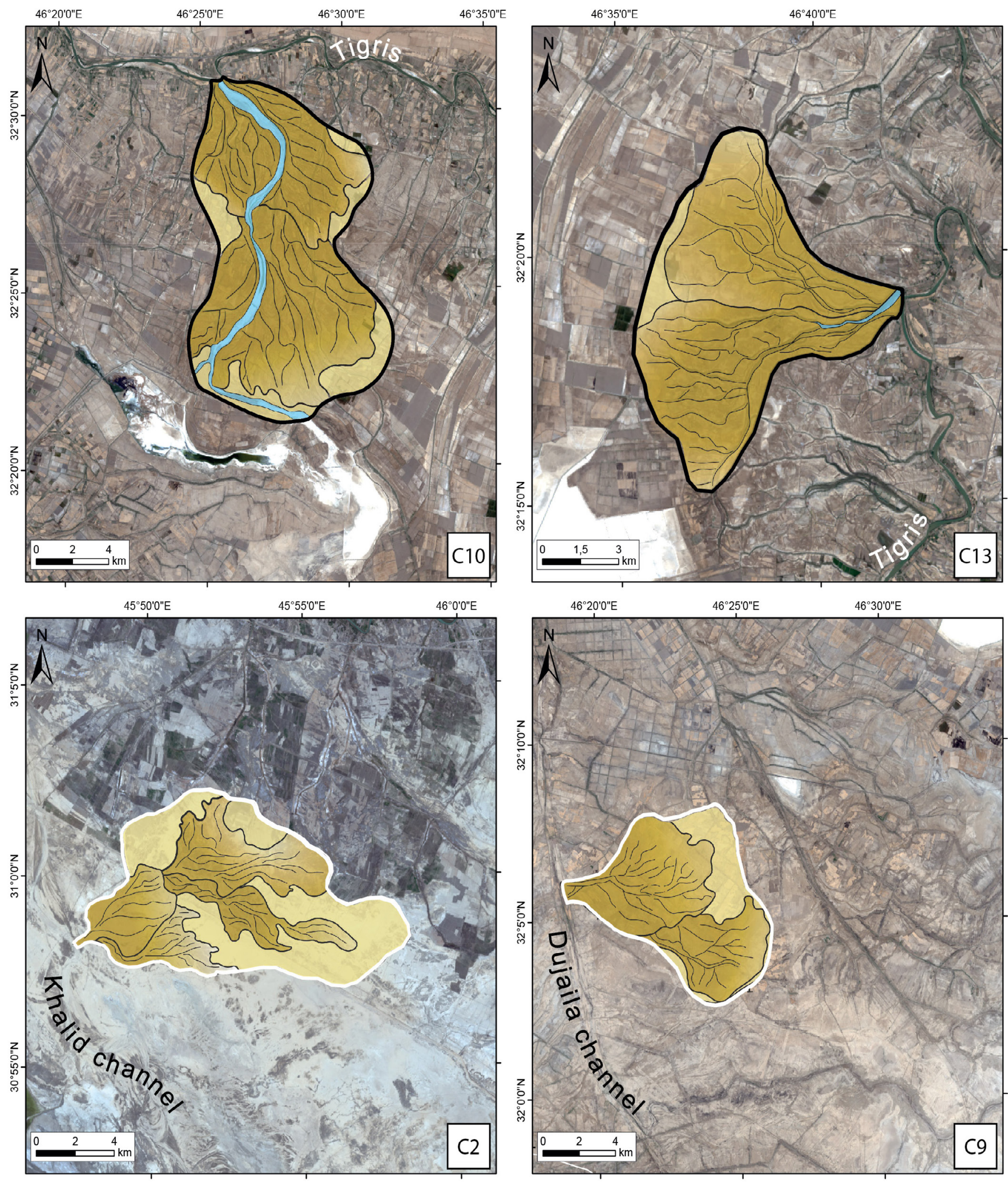

Legend

\begin{tabular}{lll}
$\square$ Main crevasse channel & Crevasse deposit & 3 Active crevasse \\
Crevasse channel & $\square$ Crevasse - floodplain deposit & 3abandoned crevsse \\
\hline
\end{tabular}

Fig. 4 - The re-mapping of active (C10 and C13) and abandoned (C2 and C9) crevasse for highlighting the hierarchy of the flood event (Iacobucci et al., 2020). 
especially where the population is mainly settled along the rivers. Thus, the methodological approach here proposed can potentially enhance the knowledge about the Holocene human-environmental interactions, which deeply modified the landscape of the LMP.

The waterscape of the LMP shows an incredible variety of fluvial landforms, both active and relict, which reflect the complexity of the Holocene landscape evolution and its morphodynamics. The rapid shift of the Persian Gulf shoreline during the last 10,000 years and the occurrence of the HCC have mainly controlled the fluvial morphodynamic of the Tigris-Euphrates fluvial system. Moreover, the favourable environmental conditions led the early human societies to settle along the numerous watercourses of the MP, developing one of the Early River Valley Civilization. Thus, the taming of nature allows the onset of a new form of cultural adaptation such as the peasant farming societies, which replaced the natural ecosystem with the agricultural ones.

The first irrigation technology was the levee breaks for irrigating the crops through floods, developing floodbased farming. The ongoing levee breaks favoured the occurrence of the fluvial avulsion processes, whose geomorphological and sedimentological evidence are the numerous crevasse splays recognizable along both active and ancient river channels composing the lowermost sector of the Tigris-Euphrates fluvial system. The focus on the fluvial avulsion processes leads to answering the open questions for the study area. As concerning the response of the fluvial morphodynamic along the Lower Mesopotamian floodplain, the insufficiency of field-based data and geo-chronological constraints are the main data gap for exhaustively answering the first question. Anyway, the recognition of several fluvial landforms, both active and relict, is the main evidence of the change in the fluvial morphodynamic and landscape. Despite the incomplete response to the first question, the issue of the remote sensing approach feasibility for recognizing the state of activity of the avulsion processes is fully resolved. Thanks to the integration of the multispectral analysis and the topographic analysis of the micro-relief, the crevasse splays are recognized as evidence of both alluvial channels and river deltas morphodynamics. The improved recognition and mapping of active and relict fluvial landforms reflect the sensitivity of the Lower Mesopotamian fluvial system to external disturbance, mainly connected to climate oscillations, shoreline shifting, and human activities.

\section{ACKNOWLEDGEMENTS}

This research has been founded by the Doctoral School "Vito Volterra" of the Earth Sciences Department of the Sapienza University of Rome and the "Grandi Scavi" project "Digging in the Land of Sumer: archaeological excavation, study and enhancement of the site of Tell Zurghul, Ancient Nigin (Iraq)". The author thanks her Supervisor Prof. Francesco Troiani and the co-director of the Italian Archaeological Expedition to Tell Surghul/Nigin in Southern Iraq Prof. Davide Nadali. Prof. Salvatore Milli, Prof. Daniela Piacentini and PhD Paolo Mazzanti are thanked for their logistic support and helpful feedbacks during the medium-scale investigation of the avulsion processes.

\section{REFERENCES}

Abdulnaby W., Motaghi K., Shabanian E., Mahdi H., Al-Shukri H. \& Gok R. (2020) - Crustal Structure of the Mesopotamian Plain, East of Iraq. Tectonics, 39, e2020TC006225.
Aqrawi A.A.M. (2001) - Stratigraphic signatures of climatic change during the Holocene evolution of the Tigris-Euphrates delta lower Mesopotamia. Global Planet. Change, 28, 267-283.

Aslan A. (2006) - Fluvial Environments. In: Elias S.A. (ed.), Encyclopedia of Quaternary Science. Elsevier, 672-685 pp.

Benjamin J, Rovere A., Fontana A., Furlani S., Vacchi M., Inlgis R.H., Galili E., Antonioli F. Sivan D., Miko S., Mourtzas N., Feljia I. Meridith-Williams M., Goodman-Tchernov B., Kolaiti E., Anzidei M., Gehrels R. (2017) - Late Quaternary sea-level changes and early human societies in the central and eastern Mediterranean Basin: An interdisciplinary review. Quatern. Int., 449, 29-57

Bertlein P.J. (2006) - The Scales of Climate Change. In: Elias S.A. (ed.) Encyclopedia of Quaternary Science. Elsevier, 1873-1883 pp.

Blum M. \& Törnqvist T.E. (2000) - Fluvial responses to climate and sealevel change: a review and look forward. Sedimentology, 47, 2-48.

Bogemans F., Boudin M., Janssens R., Baeteman C. (2017) - New data on the sedimentary processes and timing of the initial inundation of Lower Khuzestan (SW Iran) by the Persian Gulf. The Holocene, 27, 613-627.

Bond G., Kromer B., Beer J., Muscheler R., Evans M.N., Showers W., Hoffmann S., Lotti-Bond R., Hajdas I., Bonani G. (2001) Persistent solar influence on North Atlantic climate during the Holocene. Science, 294, 2130-2136.

Bridge J. \& Demicco R. (2008) - Earth Surface Processes, Landforms, and Sediment Deposits. Cambridge University Press, New York, 832 pp.

D’Arcy M., Mason P.J., Roda-Boluda D.C., Whittaker A.C., Lewis J.M.T., Najorka J. (2018) - Alluvial fan surface ages recorded by Landsat- 8 imagery in Owens Valley, California. Remote Sens. Environ., 216, 401-414

Garzanti E., Al-Juboury A.I., Zoleikhaei Y., Vermeesch P., Jotheri J., Akkoca D.B., Obaid A.K., Allen M.B., Andò S., Limonta M. \& Padoan M. (2016) - The Euphrates-Tigris-Karun river system: Provenance, recycling and dispersal of quartz-poor forelandbasin sediments in arid climate. Earth-Sci. Rev., 162, 107-128.

Goudie A.S. (2004) - Encyclopedia of Geomorphology. $1^{\text {st }}$ ed.; Routledge, London, UK, pp. 19-21, 381-384.

Iacobucci G., Troiani F., Milli S., Mazzanti P., Piacentini D., Zocchi M., Nadali D. (2020) - Combining Satellite Multispectral Imagery and Topographic Data for the Detection and Mapping of Fluvial Avulsion Processes in Lowland Areas. Remote Sen., 12, 2243.

Jotheri J., Altaweel M., Tuji A., Anma R., Pennington B., Rost S., Watanabe C. (2018) - Holocene fluvial and anthropogenic processes in the region of Uruk in southern Mesopotamia. Quatern. Int., 483, 57-69.

Jotheri J., de Gruchy M.W., Almaliki R., Feadha M. (2019) - Remote sensing the archaeological traces of boat movement in the marshes of Southern Mesopotamia. Remote Sens., 11, 2474.

Kaniewski D., Van Campo E., Guiot J., Le Burel S., Otto T., Beateman C. (2013) - Environmental Roots of the Late Bronze Age Crisis. PLOS ONE, 8, e71004.

Kennett D.J. \& Kennett J.P. (2006) - Early state formation in Southern Mesopotamia: Sea levels, shorelines, and climate change. J. Isl. Coast. Archaeol., 1, 67-69.

Lambeck K. (1996) - Shoreline reconstructions for the Persian Gulf since the last glacial maximum. Earth Planet. Sci. Lett., 142, 43-57.

Leenman A. \& Eaton B. (2021) - Mechanisms for avulsion on alluvial fans: insights from high-frequency topographic data. Earth Surf. Proc. Land., 46(6), 1111-1127.

Macklin M.G. \& Lewin J. (2015) - The rivers of civilization. Quaternary Sci. Rev., 114, 228-244.

Milli S. \& Forti L. (2019) - Geology and palaeoenvironment of Nasiriyah area/southern Mesopotamia. In: Romano L. \& D’Agostino F. (eds.), Abu Tbeirah Excavations I. Area 1. Sapienza Università Editrice, 19-33 pp.

Roberts N. (2014) - The Holocene. An Environmental History, $3^{\text {rd }}$ ed. Wiley-Blackweel, Oxford, UK, 376 pp.

Sekandari M., Masoumi I., Pour A.B.; Muslim A.M., Rahmani O., Hashim M., Zoheir B., Pradhan B., Misra A., Aminpour S.M. (2020) - Application of Landsat-8, Sentinel-2, ASTER and WorldView-3 spectral imagery for exploration of carbonatehosted $\mathrm{Pb}-\mathrm{Zn}$ deposits in the Central Iranian Terrane (CIT). Remote Sens., 12, 1239.

Siddal M., Rohling E.J., Almogi-Labin A., Hemleben C., Meischner D., Schmelzer I., Smeed D.A. (2003) - Sea-level fluctuations during the last glacial cycle. Nature, 423, 853-858 
Sissakian V.K. (2013) - Geological evolution of the Iraqi Mesopotamia Foredeep, inner platform and near surroundings of the Arabian Plate. J. Asian Earth Sci., 72, 152-163.

Syvitski J.M.P, Overeem I., Brakenridge G.R., Hannon M. (2012) Floods, floodplains, delta plains - A satellite imaging approach. Sediment. Geol., 267-268, 1-14.

Walker M., Head M.J., Berkelhammer M., Björck S., Cheng H., Cwynar L., Fisher D., Gkinis V., Long A., Lowe J. \& Newnham R. (2018) - Formal ratification of the subdivision of the Holocene Series/ Epoch (Quaternary System/Period): two new Global Boundary Stratotype Sections and Points (GSSPs) and three new stages/ subseries. Episodes, 41, 213-223.
Walker M.J.C., Berkelhammer M., Björck S., Cwynar L.C., Fisher D.A., Long A.J., Lowe J.J., Newnham R.M., Rasmussen S.O., Weiss H. (2012) - Formal subdivision of the Holocene Series/Epoch: a Discussion Paper by a Working Group of INTIMATE (Integration of ice-core, marine and terrestrial records) and the Subcommission on Quaternary Stratigraphy (International Commission on Stratigraphy). J. Quaternary Sci., 27, 649-659.

Weiss H. (2016) - Global megadrought, societal collapse and resilience at 4.2-3.9 ka BP across the Mediterranean and west Asia. PAGES Magazine, 24, 62-63

Yacoub S.Y. (2012) - Geomorphology of the Mesopotamia plain. Iraqi Bulletin of Geology and Mining, 4, 7-32. 